\title{
Hodsong: A Monastery Ritual for a Local Wisdom Ceremony for the Monk Ranking
}

\author{
Theerapong Meethaisong, Pisit Boonchai and Kosit Pangsoi \\ Department of Cultural Sciences, \\ Faculty of Cultural Sciences, Mahasarakham University, Maha Sarakham, Thailand
}

Received 2013-07-18, Revised 2013-10-27; Accepted 2013-11-02

\begin{abstract}
The ranking order of monk in Isan, Thailand was influenced mostly from Buddhist believe and practices starting from Lanchang period and this religious believe become the common practices and the tool for local community in strengthening harmony and unity. One of the important religious ceremony calls Hodsong ceremony. The research area covered Maha Sarakham, Roi Et and Kalasin provinces which there are many Monk's hierarchy ceremony. The research procedure used the qualitative research methodology. Data were collected from related literature and field studies using interviews and focus group discussion from a group of totally 66 informants. The findings were presented by means of a descriptive analysis. This research finds; Hodsong ceremony of Isan people was evidentially found since Dvaravati period, Sukhothai (Lanna), Lan Chang, Ayuthaya, Thonburi and Rattanakosin period. It was approved from different archeological sites such as Prathat Yakhu, Um Yakhu and the other kind of evident as has been recognized as a position or ranking such as Ratchakhru and Lakkham for instance. In addition, there were some equipment that was involved within this ceremony such as the water tube or Honghod were found at Wat Wichunrat and Wat Chiangthong, including different temple in Isan. The Laab or Supannabat (a golden plate used for in scripted manuscript) was rarely found,and most of remains were reproduced. Hodsong ceremony is a religious tradition of Isan people that combined the ritual and believe together. Currently, Local Isan people still practice this ceremony in some communities with the 8 steps of preparation of instruments, Hodsong ornaments the itinerary order of the ceremony the ceremonial location the establishing ritual Baisri setting Sootkhwanbaisri or morale setting consoling and tied arms tradition. In addition, this ceremony involved with believers of direction and occasion from traditional beliefs. Despite, there were some problems such as unqualified monks, insufficient equipment and the ornaments, as well as the unreadiness from the community to continue this practice. The appropriate approach in order to preserve and develop this practice has to deal with the dynamics of community through 8 approaches as follows the benefits to the community the catchment remaining or repairing restoring explicate or develop protection preservation and demarcation and classification or setting rules or regulations for preservation. Therefore, the public administration or government, private sector and community need to have an awareness and conservation to work together urgently. The Hodsong ceremony has a long history and been practiced since Dvaravati period. The contemporary Hodsong ceremony was made into an illegal or alienated tradition of Thai state which effects to the remaining practice of community. Otherwises, the Hodsong ceremony to meet the needs of the harmony and unity of community.
\end{abstract}

Keywords: Hodsong, Monastery Ranking, Local Wisdom, Preservation and Development

Corresponding Author: Theerapong Meethaisong, Department of Cultural Sciences, Faculty of Cultural Sciences, Mahasarakham University, Maha Sarakham, Thailand 


\section{INTRODUCTION}

Hodsong ceremony is a local Isan culture that have been practiced since Buddhism has been announced as a national religion in 1257 , therefore; wat or temple become a center of community. The role of Buddhist monks was powerful in Thai society and a tradition of ordaining to study in a monkhood was essential in Isan daily life practice (Cripps, 1965).

Hodsong ceremony was influenced from Lanchang Buddhism. It was a ceremony to honor a respected monk in a community and it was one way to celebrate his higher ranking position from local villagers. People organized a ceremony to announce and celebrate a new honor status to the respected monk of their community.

The process of organizing this ceremony was started from finding a right timing and follow by preparing the Honghod (water tube), the location-a ceremonial stage, appropriated ornaments including new robes. Hodsong tradition has 2 different kinds of purposes. The first kind was for the high respected monk of the community and the second one was for the monks who pass the examination. Therefore, Hodsong ceremony was a tool to unite people in Isan community. At present time, the Hodsong ceremony was decreased in practice; due to the modernization that was highly impact on Isan people and community.

\section{MATERIALS AND METHODS}

The qualitative research methodology was used. Data were collected from related literature and field studies. The research was conducted using a nonstructured interview form and focus group discussion with a group of totally 66 informants. The collected data were checked for correctness and completeness using the methodological triangulation technique. The research subsequently presented by means of a descriptive analysis.

\section{RESULTS}

This research finds Isan people practice this Hodsong ceremony for a long time which has shown since Davarati period. The important evidence are Prathat Yakhu Sema Inscription, declining Buddha image at Phu Poa includes Buddha image of Marnwichai at Suwannawat temple, historical site of Um Yakhu.
The word "Pu Khru" had been first recognized during Sukhothai period where the King Ramkhamhaeng inscription was founded near the left bank of Mekong River. In this inscription found that King Pothisarnrach and King Chaichettha had arranged this Hodsong ceremony during their throne for an approval a higher ranking of the monk. During Lan Chang period found the complete Honghod or Hanghod (water tube) at Wat Wichunratch and Wat Chiangthong and in the Ayuthaya-Thonburi period discovered that the Ratchakhru rank was Chao Ratchakhru Luang Phonsamek and the Lakkham rank as well as the wall painting of Hondsong ceremony at Wat Palealai, Nongpok Village, Dongbang Sub-district, Nadoon District, in Mahasarakham province.

During Ratanakosin period found that the Hondsong ceremony was widely spread all over the Northeastern Thailand in particular the Lakkham rank was qualified as same as the Head of Provincial administration as founded at Wat Mahaphon, Thakhonyang sub-district, Kantarawichai district, Mahasarakham province. The first four head of Mahasarakham Provincial administration were Lakkham Suwandee, Lakkham Priam, Lakkham Mum and Lakkham On. Besides, Honghod was found allover Isan. However, the Hondsong ceremony was complimented with the local believe which are Brahman and spiritual believes (Kirsch, 1967; 1977; Winichakul, 1994); as a result Isan Buddhism style that is similar to the Lanchang Buddhism.

The current situation of this ceremonial practice was effected by the transformation period "Patirup Huamuang" which means reforming the country. In this period, it had given a prohibition to any community or monks to practice this ceremony which causes the numbers of practices decreased. From the research found that the ceremony survived form some communities practices follow 8 steps which are the equipments, the combination, ceremony order, ceremony location, the establishing ceremony, Baisri bowl setting, Sootkwan Baisri (the morale praying) and Riakkhwan (consoling or hearten) Phukkhaen (ceremony for blessing and prosperity and tide the string on one hand side). Moreover, the ceremony also involved with the perception of direction and right timing as had been believed in the past. However, there were some problems within this practice such as lack of numbers of qualified monks, insufficient equipment and the ornaments, as well as the unreadiness from the community. 
The preservation and development strategies for this ceremony has to rethinking for the community value and the consciousness of each community in order to appreciate and learn how to preserve, reproduce, promote, protect and conserve in different categories, types or to introduce some regulations for a preservation. In additions, local government and public administration, private sectors and community have to show their willingness to preserve and develop this project in practice.

\section{DISCUSSION}

The Hodsong ceremony is a basic practice today as folk wisdom that links the community to the unity and it was originally a ritual to meet the needs of the community in creating harmony and unity. But as society changes, the ritual has been significantly reduced to a mere ritual tradition only.

I $\mathrm{n}$ the fourth reign of King Mongkut, he reformed the Huamuang system in order to make the region become a fully Thai state through the reformation of making a new history through genealogical chronicles in Rattanakosin period such as the foundation of royal history, Ratanakosin Chronicle, Royal Ratanakosin Chronicle in brief and the summary of Siamese Chronicles. In religious practice, King Mongkut had reformed the monastery through Somdet Phra Maha Samanachao Kromphraya Wachirayarnawarorot who wrote a curriculum for monks in Thailand and he produced some historical works through the Siamese chronicles. This historical textbook brought the idea concept to unite the whole country for one state nation. The Siamese nation state was clearer in this period than other before. Isan region in particular, there was a proclaiming announced and changed a new name for Monthon or precinct in 1899 by appointing Phrachao Boromwongthoe Kromluang Sanpasitthiprasong as the northeastern regional councilor. In a royal proclaiming has a message mentioning that in every towns have to put the word " in compulsory as Thai citizen only" as a compulsory stamp for any government affairs such as for the survey of population census or any business to get contact with commons. It was prohibited to fill other kinds of nationality or such as Laos, Khmer, Suay nor Phutai, as it was used in the past. It is therefore continue practice up to the present time. As a result from this law enforcement, the Hodsong ceremony was claimed as a Lao ethnicity ceremony, it was therefore prohibited and been canceled in 9 April 1913. This phenomena can be understand as an innovation of being thai state in establishing a hegemony over Isan region and produce a new identity of Isan instead of Laos, in order to replace the Laoness in this region (Keyes, 1967).

Although law enforcement will defuse the situation, community is trying to do the Hodsong ceremony but It does not have administrative implications of the clergy or monk who had authority in each local area which a community participate in the affairs of the clergy which caused the priest turned to pay attention the important of priest's title that appeared in central Thailand, which has a centralized system of governance by the Sangha. As a result, the immanence Hodsong traditional role gradually disappeared from the community. The rest is just a typical ancient ritual only. Guidelines for the conservation and development need to create a sense of community awareness of the value of ritual of Hodsong to influence the creation of unity, unity to the community and stimulate learning and encourage activities that lead to the conservation together.

\section{CONCLUSION}

The Hodsong ceremony has a long history and been practiced since Dvaravati period, Sukhothai (Lanna), Lan Chang, Ayuthaya, Thonburi and Rattanakosin period but has been declared canceled during the Huamang reform at Ubonratchathani province. Notwithstanding, some communities still practice this ceremony.

The contemporary Hodsong ceremony was made into an illegal or alienated tradition of Thai state which effects to the remaining practice of community. Some community had canceled this ceremony due to this obstacle, but for the survived community is only been a part of the ceremony to fulfill wishes to deceased relatives only.

In order to preserve Hodsong ceremony to meet the needs of the harmony and unity of community, it is necessary for a community to turn an attention to realize the value of the Hodsong ceremony as a basic local wisdom that has been inherited from ancestors. Then, this ceremony should be held and preserve before this tradition is absolutely lost from the community.

\section{ACKNOWLEDGEMENT}

This research cannot be possible without the supports of my supervisor, colleague and financial supports from my home Faculty of Humanities and Social sciences of 
Mahasarakham University. I am therefore gratefully thank you all on this occasion

\section{REFERENCES}

Cripps, F., 1965. The Far Province. 1st Edn., Hutchinson, London, pp: 206.

Keyes, C.F., 1967. Isan: Regionalism in Northeast Thailand. 1st Edn., Southeast Asia Program, Dept. of Asian Studies, Cornell University, Ithaca, New York, pp: 86.
Kirsch, A.T., 1967. Phu Thai Religious Syncretism: A Case Study of Thai Religion and Society. Ph.D. Dissertation, Harvard University.

Kirsch, A.T., 1977. Complexity in the Thai Religious System: An Interpretation. J. Asian Stud., 36: 241226. DOI: $10.2307 / 2053722$

Winichakul, T., 1994. Siam mapped: A History of the Geo-Body of a Nation. 1st Edn., University of Hawaii Press, Honolulu, ISBN-10: 0824819748, pp: 228. 